\title{
Canada's Frontier College: Through the Lenses of Theory and Reflection
}

\author{
Dr. Glynn Sharpe \\ Faculty of Education, Nipissing University \\ 100 College Drive, North Bay, Ontario, Canada P1B 8L7
}

Tel: 1-705-474-3450 Ext: 4170 E-mail: glynns@ @ipissingu.ca

Accepted: December 17, 2011 Published: January 30, 2012

Doi:10.5296/ijld.v2i1.1323ＵRL: http://dx.doi.org/10.5296/ijld.v2i1.1323

\begin{abstract}
Canada's Frontier College has a rich and varied history of providing education for men, women and children from across Canada. This short paper explores the College's history and mandate through a multi theoretical perspective (Humanism, Transformational learning) and commences with a personal reflection regarding the College's place in contemporary education in Canada.
\end{abstract}

Keywords: Frontier College, Adult Education, Literacy, Humanism, Transformative Learning.

\section{Introduction}

Frontier College, and the work that it does across Canada, could be examined through a myriad of critical and philosophical lenses; however, this paper will focus on two of the many applicable links to the theories of adult learning that are examined and applied herein. At its very core, Frontier College makes strides to alter the lives of the men, women, and children that they serve. The Humanist and Transformative theories of adult learning will anchor the work presented here.

\section{A Brief History of Frontier College}

Frontier College was founded in 1899 by a group of young, motivated and dedicated university students and graduates form Queen's University in Kingston, Ontario (Frontier College, 2005). Simply stated, the aim or goal of the college was to make education available and accessible for workers in isolated logging, mining and railway camps. Most of the workers 
in the camps were European immigrants who spoke little or no English whatsoever and had limited formal education (Frontier College, 2005).

The Queen's students (volunteers) began their work by establishing large, tent-like classrooms at job sites around Canada. When time permitted, camp workers, of their own volition, would assemble in the makeshift classrooms in order to facilitate their reading, writing and literacy skills.

The first president of the college, Alfred Fitzpatrick, firmly believed that all people had the inherent desire and ability to learn (Frontier College, 2005). The major stumbling blocks to learning and realizing ones potential, Fitzpatrick believed, lay in the social, political and economic inequities that plague society (Frontier College, 2005). These hindrances prevented marginalized people from attending school. Fitzpatrick's philosophical platform was deeply imbedded in the college. Ideally, the college was meant to check the imbalance between social rank and opportunity.

Fitzpatrick was keenly aware that every interaction, in all potential environments, provided an individual an opportunity to learn and expand their respective capabilities. Fitzpatrick was cognizant of the fact that working people taught and learned from each other while coexisting in their respective vocations. This type of give and take informal learning environment, Fitzpatrick realized, opened the door for more formalized instruction in the workplace. Most importantly, Fitzpatrick trained his volunteers in the art of listening and responding to an individual's unique strengths; particular wants and specified needs (Frontier College, 2005). Therefore, the curriculum was tailored to the individual and could include a range of instruction from basic literacy skills, high school equivalency, and college level courses.

\section{Frontier College's Mission Statement}

At the heart of the College's Mission Statement is the belief that literacy is a vital and essential skill in today's world and a fundamental right for all human beings (Literacy: Learning for Life, n.d). Generally, the College believes that basic literacy is more than the ability to read and write; it is the capacity to understand the printed word and to put it to use in an effective manner. Through volunteer assistance, the learner is better able to realize his/her personal goals through the acquisition of knowledge and the recognition of ones true potential; awareness, in this context, opens the door for new and exciting growth opportunities and increased self-awareness.

\section{Links to Adult Education}

The Humanist Orientation is closely tied to Frontier College and its intention. The Humanist perspective and theory of adult learning stresses the importance of an individual's personal growth and development (Margo, 2001). This particular orientation aligns itself perfectly with Frontier College's mission statement. Choice, freedom of expression, and personal growth are measured at the individual level at Frontier College. According to the College, real learning can only take place when it is meaningful to the individual and his/her 
respective life. Every course a Frontier College student undertakes is meant to meet their individual needs and to help nurture their own growth and development as a functioning, contributing member of society. In addition to this, the Humanist Orientation stresses the need for choice, freedom, creativity and self-realization as essential aspects of meaningful learning (Margo, 2001).

Transformative learning stresses the need for adult educators to integrate the course content and curriculum to the broader context of the learners' lives and the issues that they encounter (Margo, 2001). Frontier College tackles the issue of adult illiteracy as course coordinators realize that an individual's inability to read and write permeates every sphere of their existence. Lacking basic literacy skills effects self-esteem, ones ability to navigate the world around them and an individual's capacity to find meaningful and lasting employment. Frontier College's mandate is to help alleviate these deep-seated personal and social problems that hinder a persons path to personal growth and self-realization.

\section{Conclusions/Future}

Frontier College will continue to grow and meet the needs of those seeking enrichment in their lives. More than 5000 Canadians are currently volunteering their time and expertise (Frontier College, 2005). Children, families, community groups, and organizations in high-need areas will continue to receive the training, workshops and conferences needed to serve those who seek assistance. The foundation for improved literacy skills have been firmly rooted and will continue to flourish with the assistance of the men and women who serve and volunteer for Frontier College.

\section{Personal Perspective}

I have always considered myself a proud and knowledgeable Canadian. I believe that I have had a good understanding of the many contributions individuals have made to my homeland that make it a world leader in many spheres of influence. Sadly, I had no prior knowledge of Frontier College and the impact it has had on countless lives in Canada. Perhaps this is a reflection of our country's educational system and the curriculum it delivers to students. The importance of the work initiated by Fitzpatrick and Frontier College was never impressed upon me as a learner. As a career educator, I must admit responsibility in my ignorance of the invaluable contributions made by Fitzpatrick and the work of the College he established. I will make a point of integrating this important part of Canadian history into the curriculum I deliver to my teacher candidates. It's never too late to integrate the life work of selfless, dedicated Canadians into the teacher training I endeavour to deliver.

On a more personal note, I am considering becoming a volunteer myself. I cannot think of a better way to give of myself to others in this regard. The exploration of Frontier College and its mandate have opened my eyes. I am grateful for this.

A quote from a Frontier College volunteer and learner will best summarize the impact the College has had on the lives of the many Canadians. 


\section{Macrothink

"Frontier College's goals are really geared to the improvement of individuals' lives, and it's a terrific feeling to be part of that. Being involved has allowed me to learn from my learners as much as they have learned from me." FC Volunteer.

"Because of FC, I feel I have the literacy skills necessary to demonstrate who I am and what I want to become. I want to do more than survive. I want to thrive. I want to feel important. FC Learner. 


\section{References}

Margo, K. (2001). Perspectives and theories of adult learning. In D. Poonwassie \& A Poonwassie (Eds.). Fundamentals of Adult Education: Issues and Practices for Lifelong Learning (Chapter 5). Toronto: Thompson Educational Publishing.

Frontier College (April, 2005). More about Frontier College. Excerpts from the European Regional Meeting on Literacy, April 2-5, Lyon, France. Available: www.frontiercollege.ca/english/aboutus/oleary/europgr1.htm

Literacy: Learning for Life (n.d). Frontier College Mission Statement. Available: www.frontiercollege.ca/english/main.htm 